\title{
USE OF AN INDIRECT ENZYME-LINKED IMMUNOSORBENT ASSAY (ELISA) TO DETECT ANTIBODIES IN AYU (Plecogiossus altivelis) VACCINATED BY IMMERSION ADMINISTRATION
}

\section{Penggunaan Indirect Enzyme-Linked Immunosorbent Assay (ELISA) untuk Mendeteksi Antibodi pada Ikan Ayu (Plecoglossus altivelis) yang Divaksinasi dengan Cara Perendaman}

\author{
Sukenda and Hisatsugu Wakabayashi ${ }^{2,3}$ \\ ')Department ofaquaculture, Faculty offisheries and Marine Sciences, \\ Bogor Agricultural University, Bogor 16680, Indonesia, \\ 2) Department ofaquatic Bioscience, Graduate School ofagricultural and Life Sciences, \\ The University of Tokyo, Yayoi 1-1-1, Bunkyo 113-8657, Japan \\ 3) IIWFish Health Laboratory, Sendagi 3-22-11-717, Bunkyo, Tokyo 113-0022, Japan
}

\begin{abstract}
An indirect enzyme-linked immunosorbent assay (ELISA) was used to detect serum antibody in ayu, Plecoglossus altivelis, immunized against Pseudomonasplecoglossicida by immersion vaccination. First, the procedure of the ELISA was optimized and the sensitivity was checked. Secondly, the formalin-killed cells (FKC) of P. plecoglossicida was administered to ayu by immersion vaccination. Two weeks after vaccination, fish were divided into two groups, one group was given booster. The level of specific antibody production of both boostered and vaccinated only fish were statistically higher than unvaccinated control fish at the time of each blood collection. However, the differences between the boostered and vaccinated only fish were not statistically significant.
\end{abstract}

Keywords : immunization, Pseudomonas plecoglossicida, ayu, ELISA

\begin{abstract}
ABSTRAK
Indirect enzyme-linked immunosorbent assay (ELISA) digunakan untuk mendeteksi antibodi pada ayu, Plecoglossus altivelis, yang diimunisasi dengan cara perendaman untuk melawan infeksi Pseudomonas plecoglossicida. Pertama, prosedur ELISA dioptimasikan dan sensitivitas dari metode ini juga diperiksa. Kemudian, bakteri Plecoglossus altivelis yang sudah dimatikan dengan formalin diberikan ke ikan ayu dengan vaksinasi perendaman. Dua minggu setelah vaksinasi, ikan dibagi menjadi dua kelompok, satu kelompok diberi vaksinasi kedua. Produksi antibodi spesifik dari ikan-ikan yang divaksinasi satu kali dengan vaksinasi dua kaii secara statistik lebih tinggi dibandingkan dengan control. Akan tetapi, tidak ada perbedaan produksi antibodi antara ikan yarig divaksanisi satu kali dengan divaksinasi dua kali.
\end{abstract}

Kata kunci : imunisasi, Pseudomonasplecoglossicida, ayu, ELISA

\section{INTRODUCTION}

There are a number of different methods of administering vaccine in fish such as injection, immersion and oral (Ellis 1988). The immersion method is one of the most promosing method of large scale immunization of fish because it is quick and easy, pertnitting a large number of fish to be readily vaccinated (Liewis et al. 1982). The method was also been reported to provide adequate protective immunity against vibriosis in ayu (Aoki et al. 1984) and in rainbow trout (Thuvander et al. 1987), pasteurelosis in gilthead sea bream (Magarinos et al. 1994), and edwardsiellosis in eel (Song and Kou 1981). Although the immersion is effective when checked by the challenge test, the serum antibodies are hardly detected by conventional methods such as the agglutination and the passive haemagglutination. Thus, it is necessary to find the sensitive methods for detecting the antibodies from the immersed-vaccinated fish.
In this study, an indirect enzyme-linked immunosorbent assay (ELISA) was applied to detect antibodies in ayu, $P$. altivelis, immunized against $P$. plecoglossicda by immersion vaccination.

\section{MATERIALS AND METHODS}

\section{Experimental Fish}

Ayu (P. altivelis) weighing about 7 gram were obtained from Yamanashi Prefectural Fisheries Technology Center, Japan and maintained at Fisheries Laboratory of The University of Tokyo, Japan as a stock of cultured ayu. The feed were not fed for one day before the experiment.

\section{Vaccine}

The vaccine used in this study was the formalinkilled bacterin (manufactured at Kyouritsu Shouji Co., 
Ltd., Tokyo, Japan) using P. plecogiossicida FPC 941 at a total concentration of $1,7 \times 1010-\mathrm{CFU} / \mathrm{ml}$. The vaccine was diluted 1: 100 in dechlorinated water shortly before used.

\section{Vaccination schedules}

Fish were taken from the stock, divided into experimental group and control group. The experimental fish were immersed in 401 of the vaccine solution for $30 \mathrm{~min}$ with aeration. Control fish were immersed in dechlorinated water for $30 \mathrm{~min}$. Two weeks after immunization, the experimental fish were divided into two groups, one of which was given a booster immersion. The booster was performed for 20 min in the same manner as the initial immunization. During vaccination water temperature was about $230 \mathrm{C}$.

Blood samples were collected from ten of ayu of each group at 2, 4 and $6 \mathrm{wk}$ following the initial vaccination. After clotting for $2 \mathrm{~h}$ at room temperature and overnight at $40 \mathrm{C}$, the serum was collected from blood by centrifugation at $3.000 \mathrm{rpm}$ for $10 \mathrm{~min}$. The sera were stored at $-80^{\prime} \mathrm{C}$ for further determining antibody titers with ELISA.

\section{ELISA}

\section{PreParation ofpositive and negative control serum}

To obtained positive control serum, ayu was injected intraperitoneal with $0,1 \mathrm{mg} / \mathrm{mL}$ formalin-killed $P$. plecoglossicida and given a booster $7 \mathrm{~d}$ later. The negative control serum was obtained from ayu reared at Yamanashi Prefectural Fisheries Technology Center in which no disease was recorded. The serum was collected as method described above.

\section{ELISA Procedure}

An indirect ELISA was carried out according to the methods described by Cussarini-Dunier (1985) and Trongvanichnam (1994). The washed cells of $P$. plecogi'Ossicida was suspended at a density $10 \mathrm{mg}$ (wet weight) $/ \mathrm{ml}$. The bacterial cells in suspension were disrupted on ice by sonicating using Ultrasonic Disruptor IJR-20OR (Tomy Seiko Co., Ltd., Japan). After filtered through sterile millipore (Niho Millipore), pore size $0,45 \mathrm{Rm}$, the oliquot was used as an antigen at

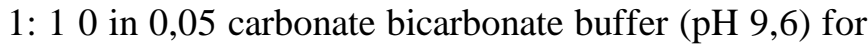
ELISA. The antigen (1 $00 \mathrm{gl} / \mathrm{well})$ was loaded onto polysterene multiple plates (Flow Laboratories, USA) and incubated at room temperature for $2 \mathrm{~h}$. Unbound antigen was removed by four successive washing with phosphate buffer saline ( $\mathrm{pH}$ 7,2) containing 0,05\% Tween 20 (PBS-Tween). To saturate antigen-uncoated sites, $100 \mathrm{gl}$ of $25 \%$ of skimmed milk (Dainihon Pharm, Japan) in PBS was added to each well and incubated for $2 \mathrm{~h}$ at room temperature. After washing four times with PBSTween, $100 \mathrm{gl}$ dilution of ayu serum (1:160 in PBS-Tween) including positive and negative control serum were added in triplicate, incubated for $2 \mathrm{~h}$ at room temperature and washed four times with PBSTween. PBS-Tween was also added to three wells as blank. One hundred microliter of anti-ayu IgM rabbit IgG diluted to $1: 200$ in PBS-Tween was subsequently added to all tested wells, incubated at room temperature for $2 \mathrm{~h}$ and washing four times with PBS-Tween. Later, $100 \mathrm{gl}$ of horseradish peroxidase labelled anti rabbit $\mathrm{IgG}$ goat IgG (Cappel, USA) diluted to 1:20.000 in PBSTween was added to each well. After incubated at room temperature for $2 \mathrm{~h}$ and washing four times with PBSTween, $100 \mathrm{gl}$ of TMB (3,3',5,5'-Tetramethylbenzidine free base tablets, Sigma, USA) solution was prepared as the manufacturer's instructions was added to wells, and incubated at room temperature for $20 \mathrm{~min}$. The reaction was stopped by adding 25 nil of $2 \mathrm{M} \mathrm{H} 2 \mathrm{~S} 04$ and optical density (OD) was measured with Microplate reader (MPR A4i, Tosah, Japan) at $450 \mathrm{wn}$. The mean absorbance values for triplicate wells were used to express antibody levels (Thuvander at al. 1993).

\section{Statistics}

Data of antibody levels were analysed by Student's t-test, respectively. Test was considered significant at probability values ofp $<0.05$.

\section{RESULTS}

Immune sera from ayu immunized with forrnalinkilled P. plecoglossicida and negative control sera from non-exposed fish were used in preliminary studies to establish optimal concentrations of antigen, ayu serum and anti-ayu IgM rabbit IgG for ELISA procedure. The relationship between OD readings and dilution of positive and negative control serum checked by ELISA was displayed in Fig. 1. 


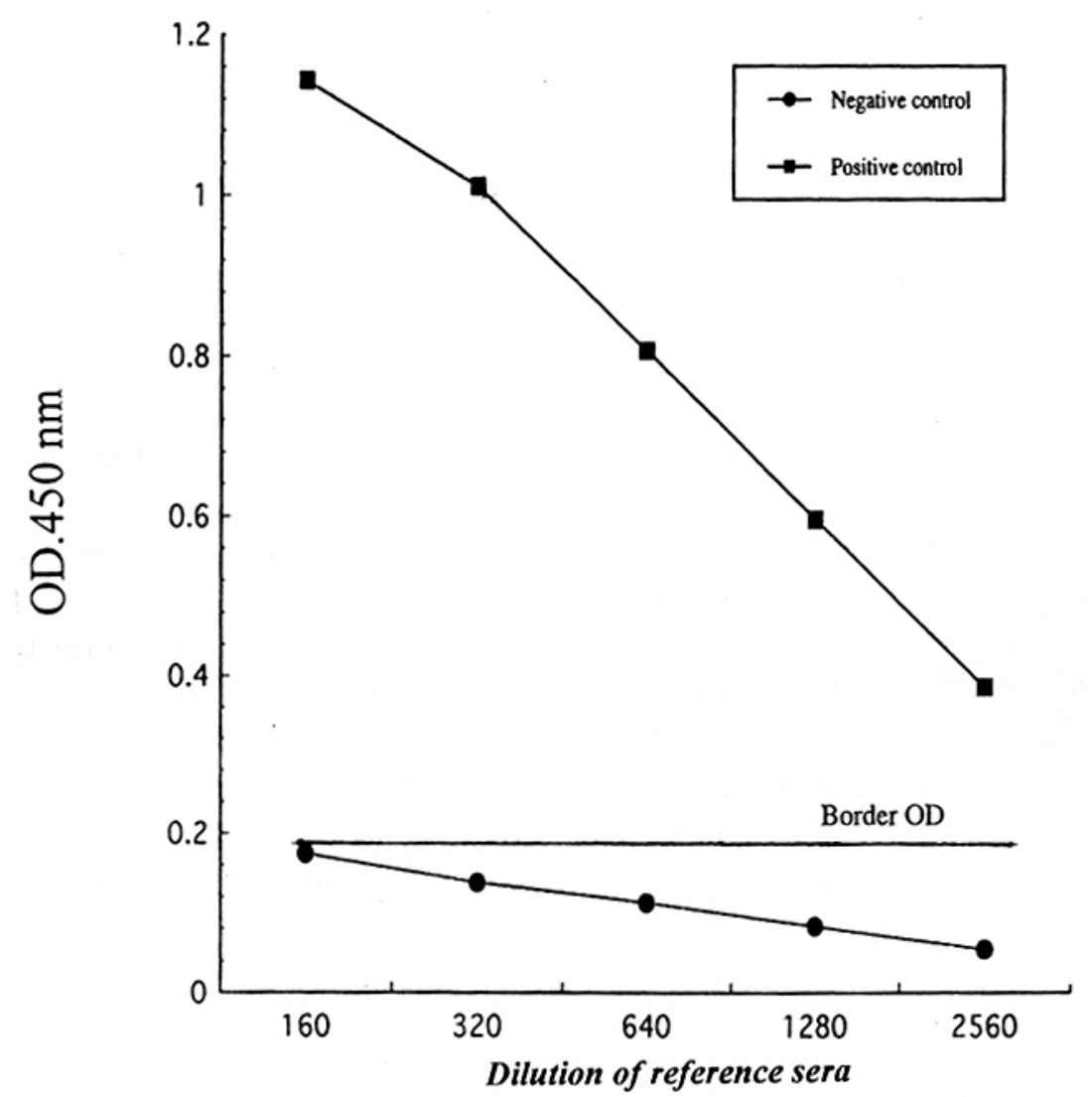

Fig. 1. Determination of the optimum OD readings to calculate the ELISA titres. The border OD readings between positive and negative sera was determined at 0,180 .

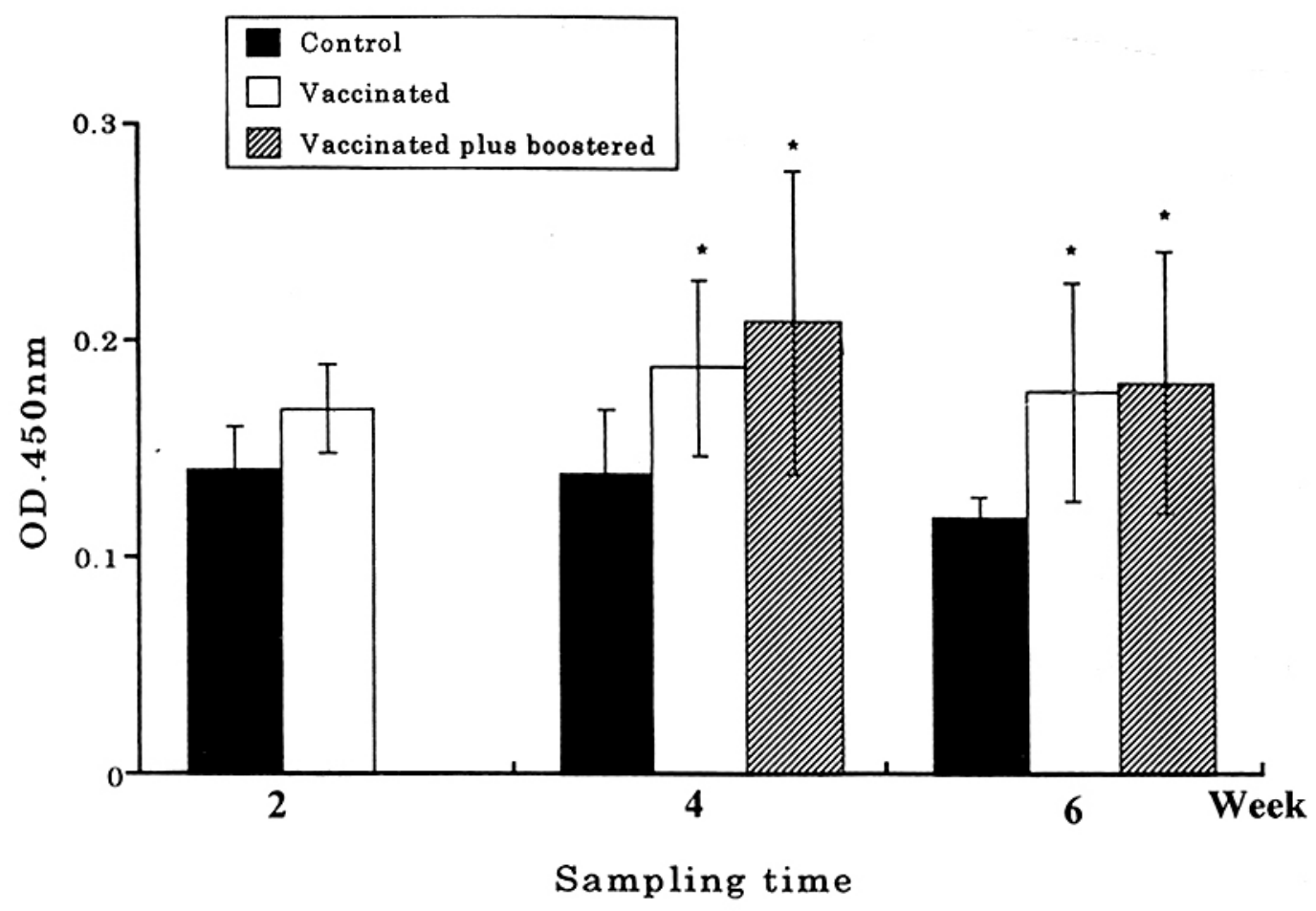

Fig. 2. Specific antibody level in the serum of ayu (mean and SD, represented by vertical bars and lines, respectively). *; Significantly different when compared with control (two sample t-test, $p<0,05$ ). 
The OD readings of negative control serum was very low in spite of 1: 160 dilution, indicating that nonspecific binding was nearly neclected. The border OD readings between positive and negative control serum was determined at 0,180 . It was determined by calculating a mean plus three standard-deviation (SD) values for OD reading of the negative control at dilution 1: 160. Fish showing titers higher than $\mathrm{OD}=0.180$ were considered to be sero-positive in ELISA. The mean OD readings of samples each regime was used to express serum antibody level at the time each blood collection.

Fig. 2. showed antibody levels of ayu at 2, 4 and 6 weeks after the initial vaccination. Whole vaccinated groups had antibody level higher than control groups. At 4 and 6 weeks after the initial vaccination, the antibody levels of vaccinated plus boostered and vaccinated only fish were significantly higher than control $(p<0.05)$. However, the differences between the boostered and vaccinated only fish were not statistically significant $(p<0.05)$.

\section{DISCUSSION}

In the immersion vaccination, antigens may absorbed by lateral line, posterior body and gills (Amend and Fender 1976) and stimulate immunocompetent organs to produce a little amount of antibodies which cannot be detected by insensitive methods such as aglutination, but can be detected by highly sensitive method such as ELISA, which was comfirmed in this study. From the result of ELISA, even though the antibody production was quite low, it indicates that the antibody levels of both boostered and vaccinated only fish showed higher than unvaccinated control fish at the time of each blood collection.

Vaccine works by inducing a protective immune response which, by virtue of the memory cells, persists for relatively long periods of time, though the precise longivity varies. Natural exposure to infection act as a booster to the immunity produced by vaccination, provided the memory cells are still present. In the absence of natural exposure, booster vaccination is necessary to maintain the level immunity (Ellis 1988). Tatner and Home (1985) found that groups of fish given booster lead to increase protection, while groups given only first vaccination result in no increased protection. The result presented in Fig. 2 indicates that a group boostered $2 \mathrm{wk}$ after first vaccination has antibody level slightly higher that a group given only first vaccination until $6 \mathrm{wk}$ after the first vaccination.

In conclusion, the indirect ELISA procedure is sensitive enough to detect serum antibody of ayu vaccinated with $P$. plecoglossicida bacterin by immersion method.

\section{REFERENCES}

Amend, D. F. and D. C. Fender. 1976. Uptake of bovine serum albumin by rainbow trout from hyperosmotic solution: A model for vaccination. Science, 192:793-794.

Aoki, T., M. Sakai and S. Takahashi. 1984. Protective immunity in ayu, Plecoglossus altivelis, vaccinated by immersion with Vibrio anguillarum. Fish Pathol., 19:181-185.

Cossarini-Dunier, M. 1985. Indirect enzyme-linked immunosorbent assay (ELISA) to titrate rainbow trout serum antibodies against two pathogens: Yersenia ruckeri and Egtved virus. Aquaculture, 49:197-208.

Ellis, A. E. 1988. General principlesof fish vaccination. In: Fish Vaccination. (ed. By A.E. Ellis). Academic Press. London. 255p.

Liewes, E. W., R. H. V. Dam, M. G. Vos-Maas and R. Bootsma. 1982. Presence of antigen sensitized leukocytes in carp (eyprintis carpio L.) following bath immunization against Flexibacter columnaris. Vet. Immunol. Immunopathol., 3:603-609.

Magarinos. B., J. L. Romalde, Y. Santos, J. F. Casal, J. L. Barja and A. E. Toranzo. 1994. Vaccination trial on gilthead seabream (Sparus aurata) againstpasteorella piscisida. Aquaculture, 120:201-208.

Song. Y. L. and G. H. Kou. 1981. The Immuneresponses of eel (Anguilla .ial)oiiica) against Edwardsiella anguillimort@fera as studied by immersion methods. FishPathol., 15:249-255.

Tatner, M. F. and M. T. llorne. 1985. The effect of vaccine dilution, length of immersion time, and booster vaccination of brown trout, Salmo trutta, with Ye,rsinia ruckeri (ERM) vaccine. Aquaculture, 46:11-18.

Thuvander, A., T. Hongslo, E. Jansson and B. Sundquist. 1987. Duration of protective immunity and antibody titres measured by ELISA after vaccination of rainbow trout, Salmo gairdneri Richardson, aginst vibriosis. J. Fish 1)is., 10:479486.

Trongvanichnam, K. 1994. A study on vaccination of eel, Anguilla japonica: Detection of the antibodies by enzyme-linked immunosorbent assay (ELISA). Thesis. The University of Tokyo. 